\title{
Phenol as grinding material in RNA preparations
}

\author{
Martine Maes ${ }^{1,2}$ and Eric Messens ${ }^{2, *}$ \\ ${ }^{1}$ Laboratory of Fytopathologie and ${ }^{2}$ Laboratory of Genetica, Universiteit Gent, Ledeganckstraße 35, \\ B-9000 Gent, Belgium
}

Submitted March 20, 1992

RNA is actively degraded by nucleases when the cell structures are destructed by the slightest thawing of frozen samples. Exceptionally high RNA yields suggest that in the presented method, frozen phenol perforates the cell walls, meanwhile protecting the nucleic acid content. Two independent applications of the method are presented facing difficulties as RNA extraction from (i) scarcely available sample material, collected and kept in liquid nitrogen, and (ii) recalcitrant cell types. Total RNA preparations are tested for quality and yield.

(i) For the construction of cDNA libraries, RNA has to be extracted from liquid immature wheat endosperm. Maturation has to be stopped in liquid nitrogen. The tissue has to be prepared from kernels under frozen conditions. The method produced 1.4 to $1.7 \mathrm{mg}$ total RNA from $1 \mathrm{~g}$ endosperm tissue. The quality of the poly $(\mathrm{A})^{+}$-enriched RNA is determined by analyzing the in vitro translation products and by isolating several $\geq 3 \mathrm{~kb}$ cDNA clones. Other efficient methods only extract between 0.1 and $0.5 \mathrm{mg}$ total RNA from $1 \mathrm{~g}$ of plant tissue $(1-3)$.

(ii) Total RNA was prepared from plant associated gramnegative bacteria and from Rhodococcus fascians, a gram positive, recalcitrant to cell disruption (J.Desomer, pers. comm.). Starting from a $0.7 \mathrm{~g}$ log phase-grown bacterial pellet, an average of $12 \mathrm{mg}$ total RNA was extracted from the gram-negatives and $1.2 \mathrm{mg}$ total RNA from $R$. fascians. Extremely low amounts of Rhodococcus RNA are produced with hot phenol extraction, (4). Lysozome pretreatment of the cell wall $(10 \mathrm{mg} / \mathrm{ml}$, and PEG6000 $30 \%$ in TE) results in degraded RNA preparations.

Protocol. Three $\mathrm{ml}$ of phenol, equilibrated with a Na-acetate buffer (50 mM Na-acetate, pH 5.1, 10 mM EDTA), is frozen in a mortar filled with liquid nitrogen and ground with a heavy pestle to a fine powder. Frozen sample material (0.02 to $4 \mathrm{~g}$ ), submerged in liquid nitrogen, is ground for 6 minutes with the phenol. During this homogenization, the sample/phenol powder mix is permanently frozen by adding liquid nitrogen. After thawing by adding $3 \mathrm{ml}$ of SDS (1\% in the buffer), the suspension is heated to $60^{\circ} \mathrm{C} \mathrm{(10} \mathrm{minutes).} \mathrm{Cooling} \mathrm{on} \mathrm{ice,} \mathrm{phase} \mathrm{separation}$ centrifugation, a second phenol/chloroform/isoamylalcohol (25:24:1) extraction and two chloroform/isoamylalcohol (24:1) extractions of the buffer phase are done. RNA is precipitated in $0.3 \mathrm{M} \mathrm{Na}$-acetate (pH 5.8) and 2.5 volumes of ethanol. The pellet $(12,000 \mathrm{~g}, 10$ minutes $)$ is washed with $70 \%$ ethanol, dried and redissolved in DEPC-treated water. The high molecular weight RNA fraction can be precipitated by incubation at $0^{\circ} \mathrm{C}$ for 3 hours in $2 \mathrm{M} \mathrm{LiCl}$ and centrifugation (15 minutes, 12,000 g). Contaminating polysaccharides can be precipitated in a gelatinous pellet $\left(0.2 \mathrm{M} \mathrm{NaCl}, 30\right.$ minutes, $0^{\circ} \mathrm{C}$, centrifugation for 10 minutes, $10,000 \mathrm{~g}$ ) (5). Ethanol precipitation of the supernatant yields pure RNA.

\section{ACKNOWLEDGEMENT}

The authors thank Jan Desomer for helpful discussion.

\section{REFERENCES}

1. Murray,M.G. and Thompson,W.F. (1980) Nucleic Acids Res. 8, 4321-4325.

2. Taylor,B. and Powell,A. (1982) BRL Focus 4, 3.

3. Logemann,J., et al. (1987) Anal. Biochem. 163, 16-20.

4. Alba,H., et al. (1981) J. Biol. Chem. 256, 11905-11910.

5. Condit,C., et al. (1983) Gene 25, 101-108.

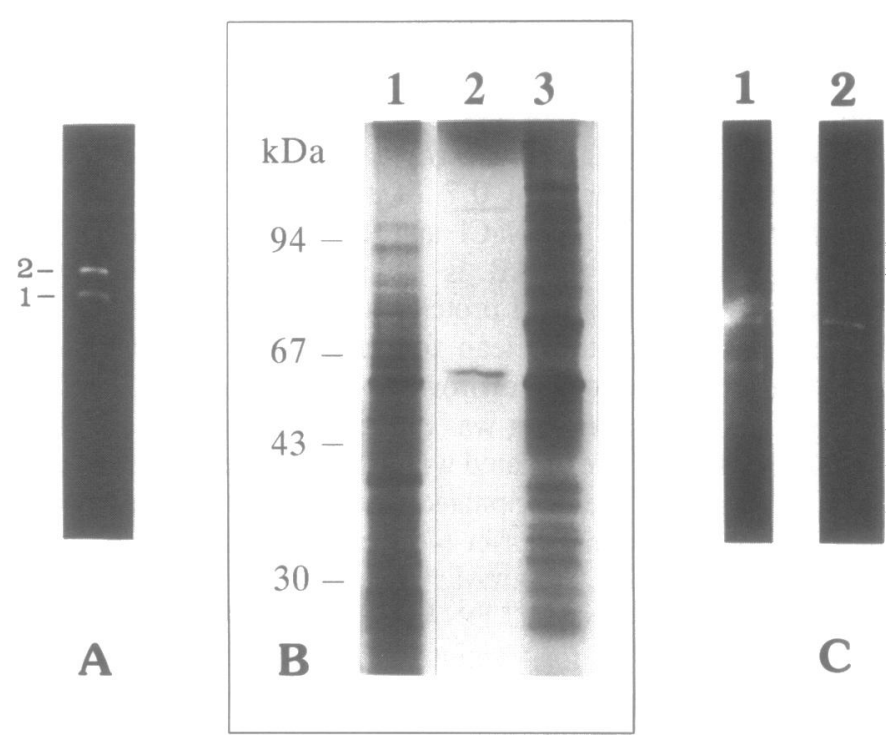

Figure 1. Gel electrophoresis. (A) Agarose: total wheat endosperm RNA, 18S (1) and 25S rRNA. (B) Polyacrylamide: in vitro translation products from 14-dayold wheat endosperm poly(A) ${ }^{+}$RNA. Lane 1 , translation with $1 \mu \mathrm{g}$ of poly(A) ${ }^{+}$ RNA; lane 2, negative control; lane 3, positive control with $1 \mu \mathrm{g}$ yeast mRNA. (C) Agarose: RNA isolations from Rhodococcus fascians. Lane 1, hot-phenol extraction from lysozyme/PEG-treated cells; Lane 2, this method, 16S and 23S rRNA.

\footnotetext{
* To whom correspondence should be addressed
} 